\title{
PLAN PLESZEWA Z XIX WIEKU - WIZUALIZACJA TEMATYCZNA
}

\author{
DARIUSZ LOREK \\ Uniwersytet im. Adama Mickiewicza w Poznaniu, \\ Wydział Nauk Geograficznych i Geologicznych, \\ ul. B. Krygowskiego 10, 61-680 Poznań
}

\begin{abstract}
In the early 19th century, cartographic studies typically satisfied military or administrative needs. The idea behind drawing a map of Pleszew in 1806 was to show the condition of the city following a great fire. The plan distinguishes between the burnt down areas and ones saved from the fire. While the legend is small, including few explanations and the markings on the sheet are moderately distributed, the analyzed city map is a valuable resource of information which can be presented in the form of thematic visualizations. The article presents studies into the information provided by the map of Pleszew in terms of the scope of content and its spatial distribution; a method of arrangement thereof has also been proposed. The decision to attribute specific objects to separate layers has offered an opportunity of selecting the content according to various criteria and presenting it in the form of thematic visualizations.
\end{abstract}

Keywords: city map information resource, nineteenth-century cartography, thematic visualization

\section{WPROWADZENIE}

Rozpatrując rozwój kartografii od XIX w., zauważamy przełom w zakresie jej pojmowania jako dyscypliny zajmującej się gromadzeniem i przedstawianiem danych przestrzennych. Przez długi czas działalność kartograficzna oznaczała głównie pozyskiwanie dokładnych danych o terenie w celu przedstawienia na papierze fragmentu przestrzeni. Według Taylora (1991) czasy współczesne, przez wykorzystanie komputerów i cyfryzację danych, nadały kartografii nowy wymiar polegający często na porządkowaniu informacji, co ma umożliwiać jej optymalne wykorzystanie.

Wykonywanie opracowań kartograficznych na początku XIX w. związane było ze zbieraniem informacji o terenie głównie na potrzeby militarne, administracyjne, a także z działaniami polegającymi na gromadzeniu danych, które wówczas podejmowano, np. spisy ludności (Edney 1996). W przypadku Pleszewa ważnym czynnikiem, który zadecydował o powstaniu planu, był pożar z 1806 r. W pożarze tym spłonęła znaczna część miasta (Gulczyński 2012). W tym samym roku wydano opracowanie ukazujące stan miasta po katakliźmie. Plan przedstawiał układ topograficzny miasta (drogi, place, zabudowę) oraz podział na działki wraz z ich numeracją. Ta treść stanowiła podkład dla 
tematu planu, jakim były obszary zniszczone przez pożar. Pomimo niedużej legendy złożonej z kilku objaśnień i umiarkowanej gęstości rozkładu oznaczeń na arkuszu opracowanie cechuje wartościowy zasób informacyjny, który można wyrazić w postaci wizualizacji (map) tematycznych. Badanie zakresu treści i jej rozkładu przestrzennego było podstawą do uporządkowania wszystkich informacji występujących na planie. Przeprowadzona procedura zapisu i wizualizacji treści XIX-wiecznego planu stanowi propozycję postępowania $\mathrm{z}$ archiwalnymi mapami w celu zwiększenia ich potencjału badawczego.

Celem przeprowadzonych badań było określenia zasobu informacyjnego planu Pleszewa pochodzącego z pierwszej połowy XIX w. oraz zaproponowanie sposobu uporządkowania treści przez jej wektoryzację do osobnych warstw i przedstawienie w postaci kilku wizualizacji tematycznych. Analizie poddano zakres treści, jak również jej rozkład przestrzenny. Podejście do badania miało charakter typowo kartograficzny i miało służyć wskazaniu możliwości szerszego wykorzystania historycznego opracowania w badaniach opartych na użyciu cyfrowych modeli danych przestrzennych.

\section{METODYKA}

Nawiązując do badań Buczka (1963) w kwestii prac z historycznymi materiałami kartograficznymi, przyjęto kolejność postępowania. Na początku przedstawiono podstawowe informacje o planie (okoliczności wydania, skala, rozmiar, orientacja), a w dalszej kolejności przeprowadzono badanie treści topograficznej. Najpierw przeanalizowano zakres legendy, a następnie porównano go z zakresem i rozkładem na planie. Ten etap ukazał duży udział i znaczenie informacji przedstawionej w postaci opisowej. W kolejnej części przedstawiono cyfrową postać zapisu zasobu informacyjnego według zaproponowanych wizualizacji tematycznych.

\section{Informacje o planie}

W tytule planu Pleszewa z pierwszej połowy XIX w. wskazuje się na temat prezentowanego zjawiska, jakim było przedstawienie przestrzeni miasta po pożarze: „Plan von den Plätzen der abgebrandten Stadt Pleschen vermessen im Monat Juli 1806 durch den Bauinspector Grapow copiert im Juli 1827 durch Kaeufer Feldwebel“. $Z$ tytułu wynika również, że pomiary terenu przeprowadzono po pożarze w lipcu 1806 r. Nadzorował je inspektor Grapow. Tytuł zapisano na osobnym fragmencie papieru, który z uwagi na treść musiał być później dodany do mapy, prawdopodobnie w momencie kopiowania planu w 1827 r. (ryc. 1).

Skalę opracowania wyrażoną w postaci graficznej opisano dawnymi jednostkami (pręty, stopy pruskie). Po przeliczeniu jej na system metryczny jednemu 
centymetrowi na mapie odpowiadało około $10 \mathrm{~m} \mathrm{w}$ terenie (skala $1: 1000$ ). Rozmiary planu wynoszą 102,5 cm wysokości oraz 134 cm wzdłuż dłuższej krawędzi. Był on sklejony z czterech arkuszy papieru o rozmiarach około $52 \times 70$ $\mathrm{cm}$. Zamieszczono również ozdobny rysunek kierunków świata, z którego wyni$\mathrm{ka}$, że dla planu przyjęto orientację północną. Badany plan jest przechowywany w zbiorach Archiuwm Państwowego w Poznaniu, Mapy Landratur, sygn. L. 49.

\section{Zasób legendy}

Po lewej stronie arkusza zamieszczona została legenda odnosząca się do wybranych elementów ujętych na mapie. W dosłownym tłumaczeniu dotyczyła ona objaśnienia kolorów. Zakres treści legendy zawierał osobne oznaczenia głównie dla obszarów spalonych i terenów, które uniknęły ognia. Na rycinie 1 pokazano objaśnienia, w których wyróżniono cztery wydzielenia:

1. miejsca w pełni spalone - oznaczone jasnoszarym tłem i cienkim czarnym konturem z lekko czerwonym podbarwieniem,

2. domy i obszary, które przetrwały pożar - oznaczone szarym tłem, ciemniejszym w stosunku do obszarów spalonych ze wskazaniem lokalizacji poszczególnych budowli (kolor czarny) i cienkim czarnym konturem z lekko szarym podbarwieniem,

3. niespalone stodoły i puste obszary - oznaczone jasnoszarym tłem i cienkim czarnym konturem z lekko szarym podbarwieniem ze wskazaniem lokalizacji poszczególnych budowli (kolor czarny),

4. drogi i rowy - drogi oznaczone linią z podwójnym konturem lub pojedynczą linią z lekko czerwonym podbarwieniem; rowy oznaczone pojedynczą ciemną kreską.
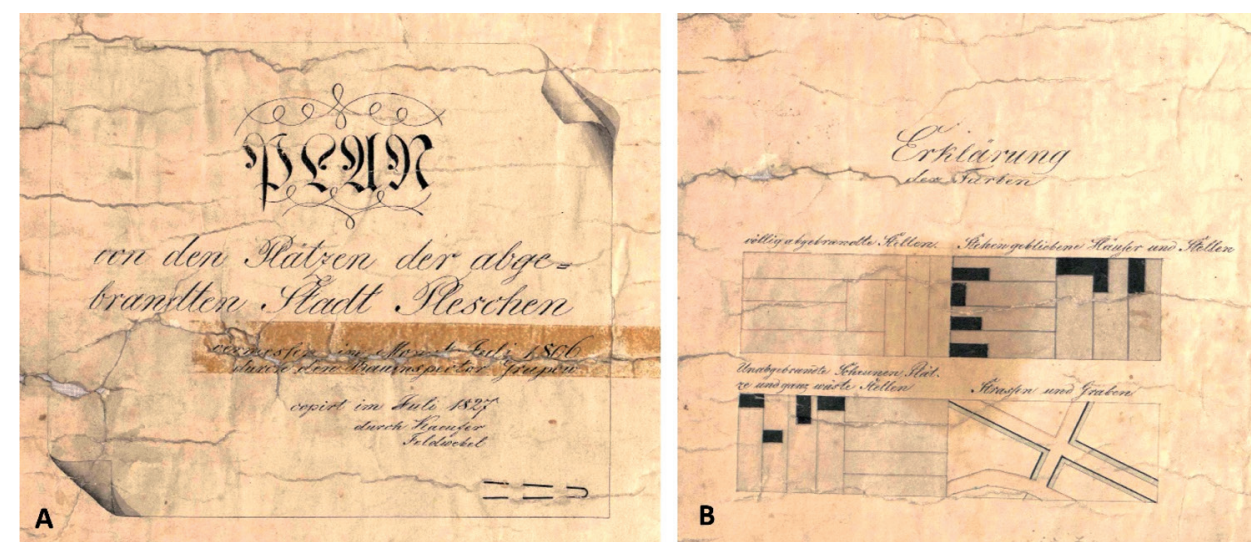

Ryc. 1. Tytuł (A) i objaśnienia (B) na planie

Fig. 1. Title (A) and explanations (B) on the city map 
Pomimo niewielu wydzieleń w legendzie ich jednoznaczna interpretacja zarówno w objaśnieniach, jak i na mapie jest utrudniona z uwagi na podobieństwo kolorystyczne przyjętych oznaczeń. Być może w momencie opracowania planu kolory były w pełni rozróżnialne, a wskutek upływu czasu nastąpiła utrata pigmentu w poszczególnych barwnikach. Nie ma różnic koloru między konturem „obszarów całkowicie spalonych” oraz „dróg” oznaczonych pojedynczą linią. W obu przypadkach ciemnej kresce towarzyszy lekkie podbarwienie kolorem czerwonym. Trudność sprawia ponadto rozróżnienie „miejsc zupełnie spalonych” oraz wydzielenia „niespalone stodoły i puste miejsca”. Cechuje je ten sam jasnoszary odcień tła, a różnicę, czasami niedostrzegalną, stanowi lekko czerwone lub lekko szare podbarwienie konturu. Niedostrzegalne na planie są ponadto różnice między domami przedstawianymi w postaci czarnych prostokątów oraz stodołami wraz z budynkami gospodarczymi, które wskazano na osobnym wydzieleniu w legendzie. Być może nie miały one rozróżnienia w barwie, a jedynie w wielkości, jednak na podstawie legendy i zapisu informacji na planie nie można tego określić.

Dla dróg przyjęto dwojakie oznaczenie. Większość dróg przedstawiono za pomocą pojedynczej kreski z lekkim czerwonym podbarwieniem. Wyłącznie na kilku odcinkach pojawiała się sygnatura o znacznie szerszej linii złożona z grubszego konturu po jednej stronie oraz wypełnienia w kolorze jasnoniebieskim. W legendzie nie przedstawiono objaśnienia dla przyjętego podziału. Sporadycznie zastosowane oznaczenie drogi może wskazywać na jej rangę lub rodzaj zastosowanego budulca. Takie kryteria stosowano na mapach pruskich w pierwszej połowie XIX w.

Opierając się na zakresie treści zawartych w legendzie, jednoznacznie można rozróżnić pierwsze dwa z opisanych wydzieleń: miejsca w pełni spalone oraz domy i obszary, które przetrwały pożar. Przyjęte oznaczenia powierzchniowe (jasne i ciemne wypełnienie) pozwalają na ogólne rozgraniczenie dwóch jakości w strukturze przestrzennej dawnego Pleszewa. Trudność pojawia się przy bardziej szczegółowym badaniu planu, kiedy widać, że dla pojedynczych działek oznaczonych jasnym wypełnieniem zastosowano szary kolor w konturze, co zgodnie z legendą oznacza obszary niespalone. Na planie jest kilka takich obszarów, dla których w celu poprawnej interpretacji należałoby odnieść się do innych źródeł graficznych lub opisowych, np. działki o numerach: 150, 152, 299, 300 .

\section{Zakres treści i rozkład przestrzenny}

Na dawnych mapach pojawiały się znaki, które nie posiadały objaśnień na arkuszach znaków umownych (Lorek 2011; De Coene i in. 2012). Na badanym planie Pleszewa również znajdowały się takie oznaczenia. W celu określania 
zasobu informacyjnego planu konieczna była weryfikacja oznaczeń występujących zarówno w legendzie, jak i na mapie. Jednocześnie przeprowadzono analizę rozkładu przestrzennego poszczególnych obiektów zapisanych na planie.

Do obiektów nie ujętych w legendzie, a występujących na mapie należy sygnatura przedstawiająca wody powierzchniowe. W objaśnieniach ujęto „drogi i rowy" i sygnatura rowu jest dostrzegalna na mapie (ciemna kreska z kropkami). Jednak dodatkowo pojawił się kolor niebieski, którego nie uwzględniono w legendzie, wskazujący na formę obniżenia terenu wypełnioną wodą. Zjawisko pojawiło się tylko raz na mapie i oznaczono je kolorem błękitnym z ciemniejszym podbarwieniem jednej krawędzi (ryc. 2). Ciek stanowił granicę pomiędzy dwoma działkami (numery 328 i 329). Wyłącznie na arkuszu użyto także oznaczenie wskazujące na miejsce przecięcia cieku z drogą. Ponadto dwukrotnie na mapie zastosowano sygnaturę $\mathrm{w}$ postaci przerywanej czarnej linii. Było to na narożniku ulic opisanych jak „Schloss Strasse” oraz „Weg von Maline” i dotyczyło działki numer 314. Drugi przykład stanowiła działka na głównym rynku o numerze 237. Nawiązując do zasad pruskiej topografii tego okresu, taki rysunek mógłby wskazywać na elementy projektowane w przestrzeni.

$\mathrm{Na}$ planie utrwalono sygnaturę liniową $\mathrm{w}$ kolorze czerwonym (pojedyncza linia ciągła). Odcień zastosowanej czerwieni był mocniejszy niż w przypadku wcześniej opisywanych wydzieleń legendy. Dzięki temu rysunek stał się wyraźny i interpretacja rozkładu przestrzennego tak zapisanych form była

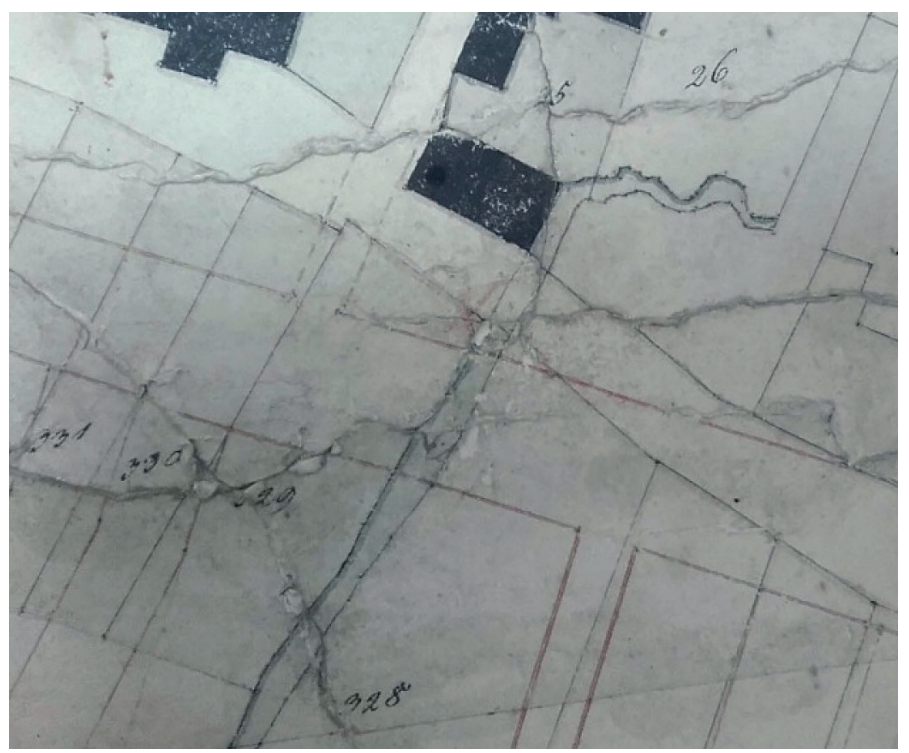

Ryc. 2. Wody powierzchniowe

Fig. 2. Surface waters 
jednoznaczna. Za pomocą tej sygnatury przedstawiono rozkład części dróg, obszary zabudowy, rynek i wyodrębniono poszczególne działki. Na niektórych odcinkach sygnatura przyjmowała styl linii przerywanej. Zarówno dla linii ciągłej, jak i przerywanej nie załączono objaśnień w legendzie. Może to sugerować, że oznaczenia te wprowadzono wtórnie na plan.

Poza intensywnym kolorem, który wyróżnia się na tle pozostałych oznaczeń, także nieznacznie zmieniony układ prezentowanych form wskazuje na odrębne wrysowanie omawianych elementów. Strukturę przestrzenną prezentowanych w nowej odsłonie obiektów cechuje uporządkowanie, tzn.: drogi mają wyrównany przebieg (niepofalowany), poszczególne ulice mają zbliżoną szerokość, obszary zabudowy są wyrównane w stosunku do osi dróg i tworzą zharmonizowaną strukturę, także sąsiadujące działki cechują się regularnym kształtem. Powstanie przejrzystego i mającego cechy form geometrycznych układu miasta musiało być oparte na rozwijających się w XIX w. technikach i metodach pomiarów geodezyjnych (Medyńska-Gulij, Lorek 2008; Engberg-Pedersen 2015). Poza „wyprostowaniem” niektórych osi komunikacyjnych czy granic działek, rysunek wykreślony czerwoną kreskę ukazuje także zmiany w strukturze przestrzennej, głównie w aspekcie wskazania nowych lub projektowanych ulic.

\section{Informacje opisowe}

Duża skala i format opracowania pozwoliły autorom planu na wprowadzenie nazw poszczególnych ulic. Należy zaznaczyć, że nie wszystkie wytyczone w przestrzeni miasta ciągi komunikacyjne zostały podpisane. Brak nazw dotyczył głównie wąskich i krótkich odcinków dróg.

Porównanie opisów na planie z publikacjami poruszającymi kwestie nazw ulic ukazało rozbieżności (Hajdasz i in. 2009; Ptak 2007). W związku z tym w tabeli 1 przedstawiono zestawienie nazw ujętych na planie i tych stosowanych współcześnie jako asumpt do dalszych badań w tym zakresie. Przykład stanowi droga opisana na planie jako „Tiniec Strasse”, która według literatury od okresu zaborów miała niemal niezmienioną nazwę (Hajdasz i in. 2009). Tymczasem aktualnie ulica ta nazywa się „Bojanowskiego”, a nazwą „Tyniec” oznacza się drogą do niej równoległą. Współczesna ulica „Tyniec” na planie opisana była dawniej jako „Quer Strasse”.

Rozważania dotyczące nazewnictwa ulic podejmował Gulczyński (2012, 2014), analizując dokładniej zapisy poszczególnych nazw i ich genezę. Drogi wylotowe z miasta miały nazwę zazwyczaj pochodzącą od nazwy miejscowości, do której prowadziły, np. Lenartowicer Strasse, Kalisher Strasse, Jarocziner Strasse. Stanowiło to dodatkowy opis przestrzeni geograficznej i zwiększało zasób informacyjny opracowania. Dla niektórych dróg nieposiadających nazw stosowano formę opisową, np.: droga z Malinia („Weg von Maline”, lub „von 
Maline”), do Marszewa („,nach Marszewo”) (ryc. 3). Nazwa ulicy „Hinter Strasse" podpisana została w części północnej Pleszewa oraz na jego południowych obrzeżach, dlatego w tabeli 1 zamieszczono dwie nazwy funkcjonujące współcześnie. W przypadku „Lenartowicer Strasse” wyodrębniono w obecnej przestrzeni dwie osobne ulice (Kilińskiego i Niesiołowskiego). Podzielona została także droga „Marszewer Strasse” (tab. 1).

Tabela 1. Dawne oraz obecne nazwy ulic Pleszewa

Table 1. Former and present names of Pleszew streets

\begin{tabular}{ll}
\hline \multicolumn{1}{c}{ Dawne nazwy ulic na planie Pleszewa } & \multicolumn{1}{c}{ Współczesne nazwy ulic* } \\
\hline Jarocziner Strasse & Poznańska \\
Hinter Strasse & Generała Hallera, Wyspiańskiego \\
Marszewer Strasse & Daszyńskiego, Marszewska \\
Tiniec Strasse & Bojanowskiego \\
Quer Strasse & Tyniec \\
Lenartowicer Strasse & Kilińskiego, Niesiołowskiego \\
Schloss Strasse & Zamkowa \\
Maliner Strasse & Sienkiewicza \\
Ziegen Strasse & Garncarska \\
Toepfer Strasse & Krzyżowa \\
Hunde Strasse & Krzywa \\
Kalischer Strasse & Kaliska \\
Nachmüchlen Strasse & Piaski \\
\hline
\end{tabular}

* Według mapy topograficznej, arkusz M-33-12-B-c-1 (skala 1 : 10 000, układ PL-UTM).

Oprócz ulic na planie opisany został również główny rynek i zlokalizowane na nim cztery figury świętych: Jana Nepomucena, Marii, Wawrzyńca i Floriana. Oznaczono je sygnaturą, która nie miała wyjaśnienia w legendzie. W sposób opisowy wskazano także miejsca związane z lokalizacją kościołów: plac kościoła farnego po prawej stronie rynku, kościół Świętego Floriana przy wjeździe do miasta od strony zachodniej oraz kościół Świętego Ducha niedaleko obecnej ulicy Świętego Ducha. W przypadku ostatniej świątyni jej wezwanie, nietypowo w porównaniu z resztą napisów, przedstawiono w dwóch językach (,,Sct. Duch oder Heilige Geist Kirche"). W odniesieniu do pojedynczej budowli zlokalizowanej przy północno-zachodnim obrzeżach Pleszewa zamieszczono informacje opisową o jej przynależności do przedmieść Malinia.

Plan stanowi cenne źródło informacji jako dokument urzędowy określający położenie, kształt i wielkość poszczególnych działek. Niemal każda wytyczona działka ma na badanym opracowaniu przypisany numer. Numeracja rozpoczyna się od działki z kościołem pod wezwaniem Świętego Floriana i wzrasta kolejno 
w kierunku wschodnim po stronie północnej obecnej ulic Poznańskiej, a kończy się na tej samej ulicy po stronie południowej numerem 339. Zazwyczaj liczby odnoszą się do wytyczonych działek, a w nielicznych przypadkach przypisane zostały do budynków, np. numery $3,4,49$. W prezentowanej przestrzeni można doszukać się pojedynczych działek bez nadanego numeru, co mogło wskazywać na ich przynależność do działki sąsiedniej. Na planie przedstawiono także kilka budynków, które znajdowały się poza obrębem opisanych działek i nie miały przypisanych numerów (np. na północ od posesji numer 2 czy wzdłuż „Jarocziner Strasse") (ryc. 3).

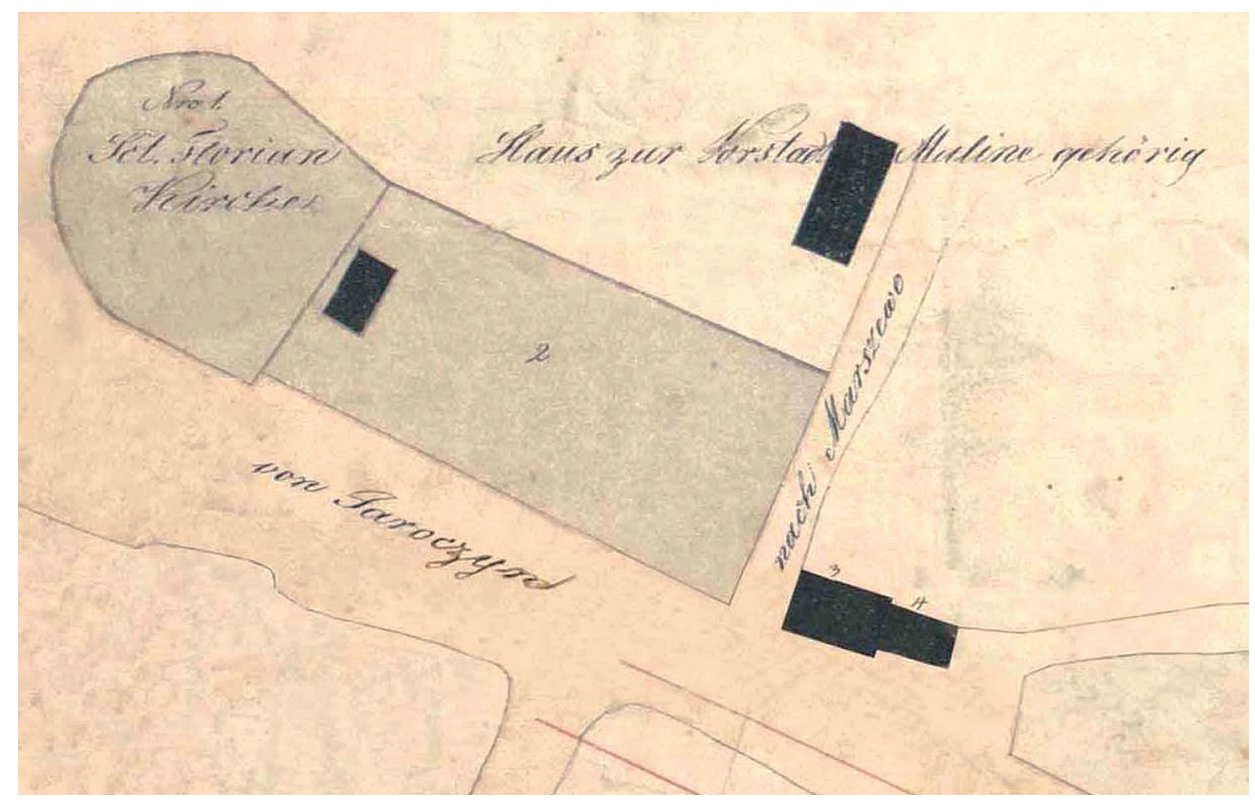

Ryc. 3. Fragment planu z opisem ulic i oznaczeniem działek

Fig. 3. A fragment of the city map with the description of streets and the designation of plots

Z uwagi na przetarcia papieru opisy dwóch działek stały się nieczytelne numer 131 i 335, jednak uporządkowany sposób ich oznaczania pozwala na odtworzenie brakujących wartości liczbowych. Ponadto na jednej posesji zapis liczby poprzedzono literą (,a130”), co mogło wskazywać na jej przynależność do sąsiadującej działki nr 130. Niejasny pozostaje opis posesji numer 303, ponieważ stosowany krój pisma wskazuje na liczbę 304, a takowy opis pojawia się w odniesieniu do sąsiedniej działki.

Oprócz wydzieleń geodezyjnych informacja opisowa wyrażała także treści ogólnogeograficzne, odnosząc się do obszarów otaczających dawny Pleszew. Wokół miasta zamieszczono informacje o polach i łąkach do niego przynależnych. 


\section{Zapis zasobu informacyjnego w postaci wizualizacji tematycznych}

$\mathrm{Z}$ zaprezentowanych powyżej badań planu dawnego Pleszewa w aspekcie zakresu treści i jego rozkładu przestrzennego wynika możliwość utworzenia wizualizacji tematycznych i zapisania zasobu informacyjnego planu w postaci osobnych warstw w modelu cyfrowym. Ideą tego podejścia było udostępnienie cennego archiwalnego opracowania do prowadzenia badań przekształceń przestrzeni z wykorzystaniem innych źródeł kartograficznych w technologii geoinformacyjnej (oprogramowanie Qgis wersja 2.18.19). Zaproponowano sposób uporządkowania i kategoryzacji wyodrębnionych na planie informacji (danych) przez utworzenie czterech wizualizacji tematycznych opartych na wektoryzacji poszczególnych elementów treści planu:

wizualizacja 1 - wektoryzacja układu dróg i placów oraz całych obszarów zabudowy, a także wód powierzchniowych,

wizualizacja 2 - wektoryzacja wszystkich działek,

wizualizacja 3 - wektoryzacja obszarów spalonych i niespalonych (zgodnie $\mathrm{z}$ legendą),

wizualizacja 4 - wektoryzacja układu dróg, placów i działek wrysowanych wtórnie.

Pierwsza wizualizacja stopniem szczegółowości odnosi się do współczesnej mapy topograficznej w skali 1:50 $000 \mathrm{w}$ układzie PUWG-1992 z 1998 r. (arkusz M-33-12-B). Decyduje o tym zakres ujętych obiektów (drogi, place, obszary zabudowy, sieć hydrograficzna) i dokładność ich przedstawienia. Utworzone warstwy ukazują rozkład przestrzenny miasta z pierwszej połowy XIX w. (ryc. 4). Widoczna jest struktura przestrzenna oparta na głównym rynku zlokalizowanym w części centralnej. Miasto miało układ turbinowy, czyli układ dróg głównych wychodzących z przeciwległych narożników rynku (Hajdasz i in. 2009; Gulczyński 2012). W postaci osobnych warstw wektorowych zapisano siatkę ulic z oddzielnym wyróżnieniem ulic oznaczonych w legendzie szeroką linią o podwójnym konturze i barwnym wypełnieniu (kolor fioletowy). Szerokość i kształt dróg oraz placów wynikały z rozmieszczenia i rozmiarów poszczególnych działek i budynków. Na niewielu odcinkach linia zabudowy oraz granice działek nie wyznaczały krawędzi drogi, wówczas oznaczono ją osobną linią. Ponadto w oddzielnej warstwie zapisano wody powierzchniowe (kolor niebieski).

Na drugiej wizualizacji tematycznej układ topograficzny został uszczegółowiony o informacje geodezyjne, prezentując podział na działki i poszczególne budynki. Na etapie wektoryzacji działek trudność stanowiło jednoznaczne określenie ich granic w sytuacjach, kiedy występowała sygnatura budynku. Jednakowy kolor użyty do przedstawienia zabudowy i granic posesji często uniemożliwiał określenie przynależności poszczególnych budowli do właściwych działek. W takich przypadkach granicę wektoryzowano tylko do krawędzi zabudowy. 


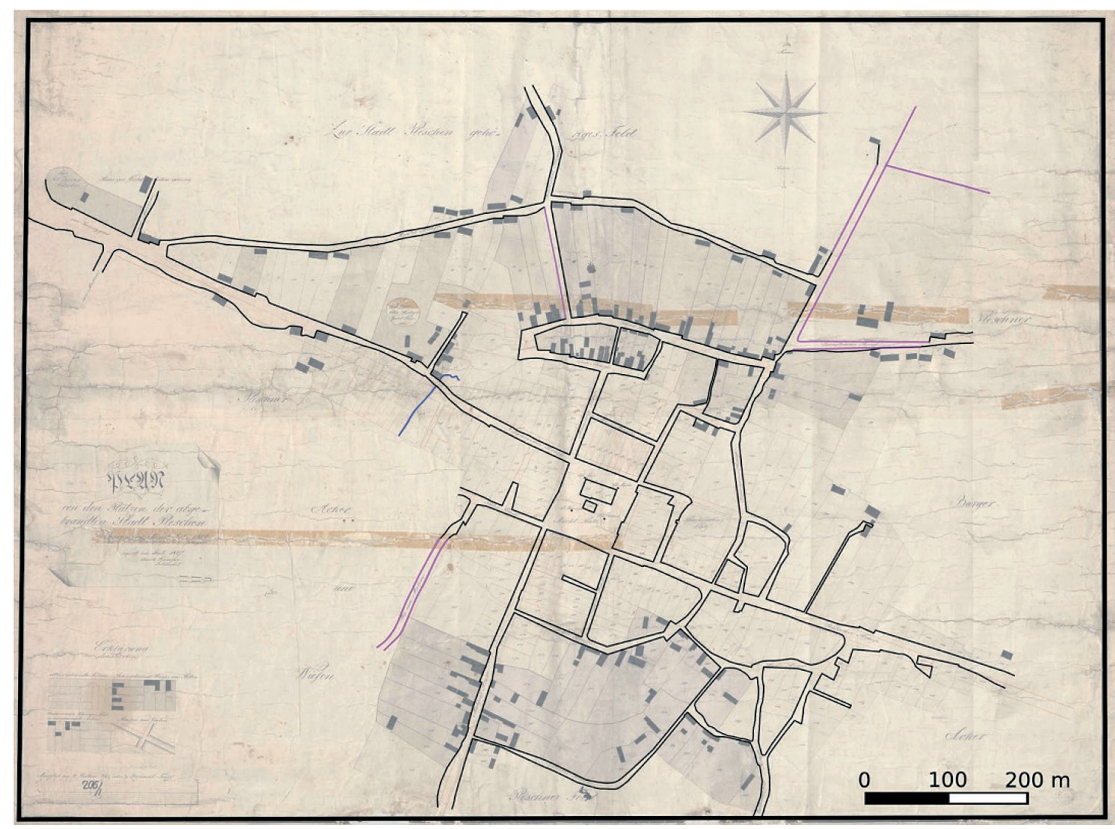

Ryc. 4. Wizualizacja tematyczna 1

Fig. 4. Thematic visualization 1

Często budynki z dwóch sąsiednich działek stykały się ze sobą, co mogło oznaczać, że miały wspólną ścianę, a granica w takim przypadku powinna być kontynuacją linii prostej ciągnącej się wzdłuż całej działki. Jednak poprawna interpretacja takich układów powinna być oparta na informacjach opisowych lub dokładniejszych wyrysach czy szkicach geodezyjnych poszczególnych budowli i działek. Na rycinie 5 pokazano drugą wizualizację tematyczną wraz z warstwą działek i wyłączoną warstwą budynków, ukazujących opisaną sytuację. Ponadto w przypadku kilku działek przebieg granic wyznaczały wody powierzchniowe.

Trzecia wizualizacja tematyczna dawnego planu Pleszewa stanowi odzwierciedlenie głównych wydzieleń legendy, czyli wyróżnienie obszarów, które przetrwały pożar (kolor żółty) i terenów spalonych (pozostały obszar). Oba typy terenu zostały zapisane w postaci osobnych warstw, co daje czytelny obraz miasta po spustoszeniu przez ogień (ryc. 6). Stworzono dodatkowo oddzielną warstwę dla obszarów, których zaklasyfikowanie nie było w pełni jednoznaczne z uwagi na podobieństwo kolorystyczne przyjętych oznaczeń omówionych podczas analizy zakresu treści legendy (kolor zielony).

$\mathrm{Na}$ ostatnią z utworzonych wizualizacji tematycznych składają się obiekty wrysowane na planie kolorem czerwonym (drogi, place i działki), które mogły dotyczyć projektu odbudowy miasta po pożarze (ryc. 7). Do osobnych warstw zapisano układ dróg, odcinki ulic wrysowanych linią przerywaną oraz podział 


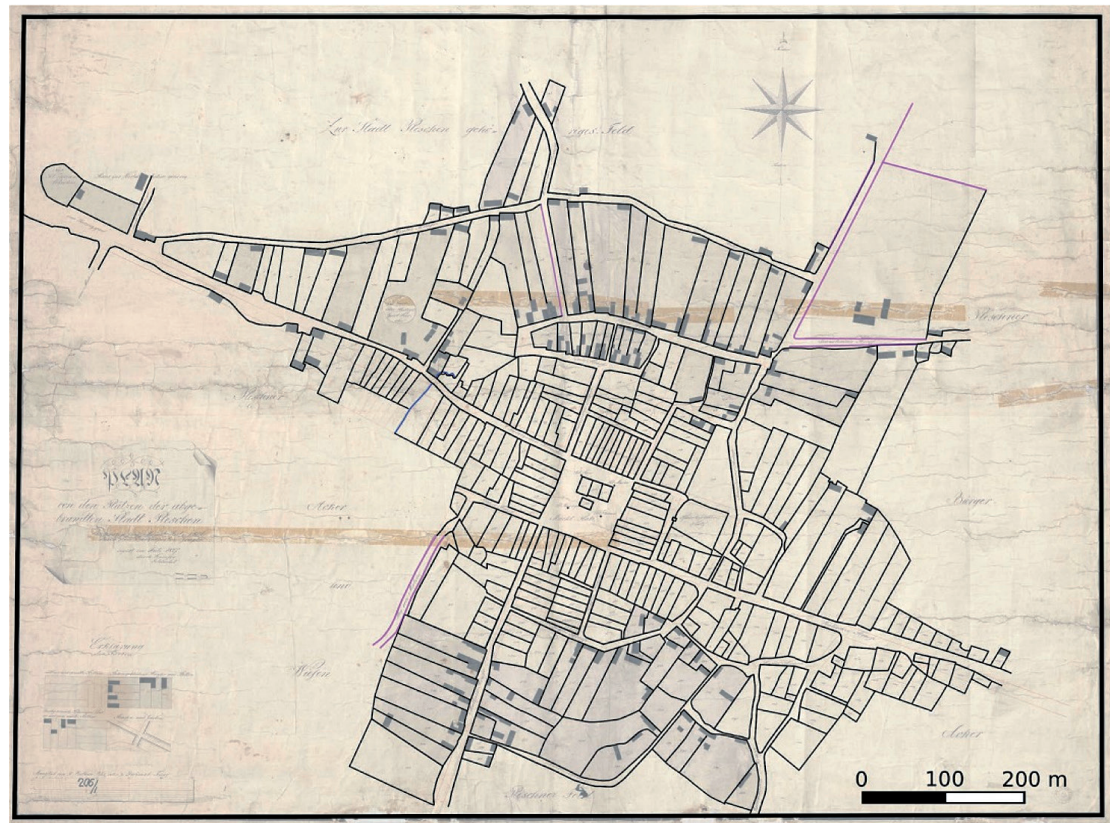

Ryc. 5. Wizualizacja tematyczna 2

Fig. 5. Thematic visualization 2

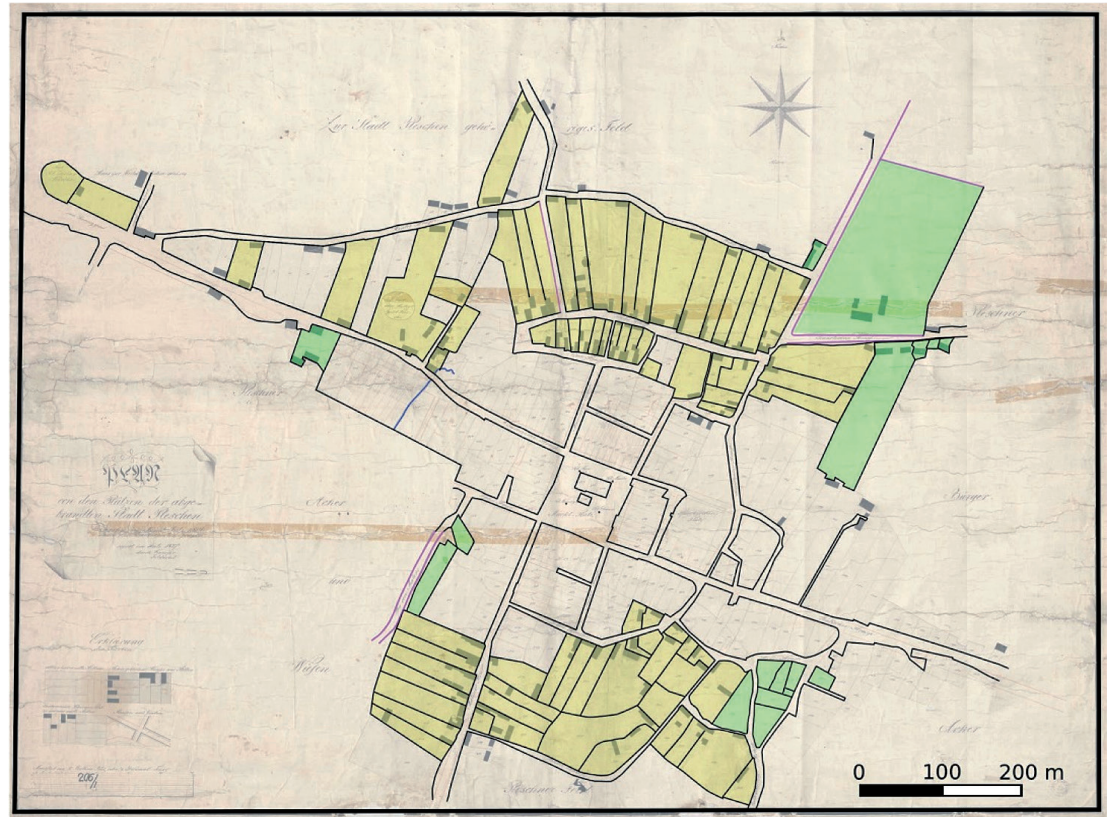

Ryc. 6. Wizualizacja tematyczna 3

Fig. 6. Thematic visualization 3 


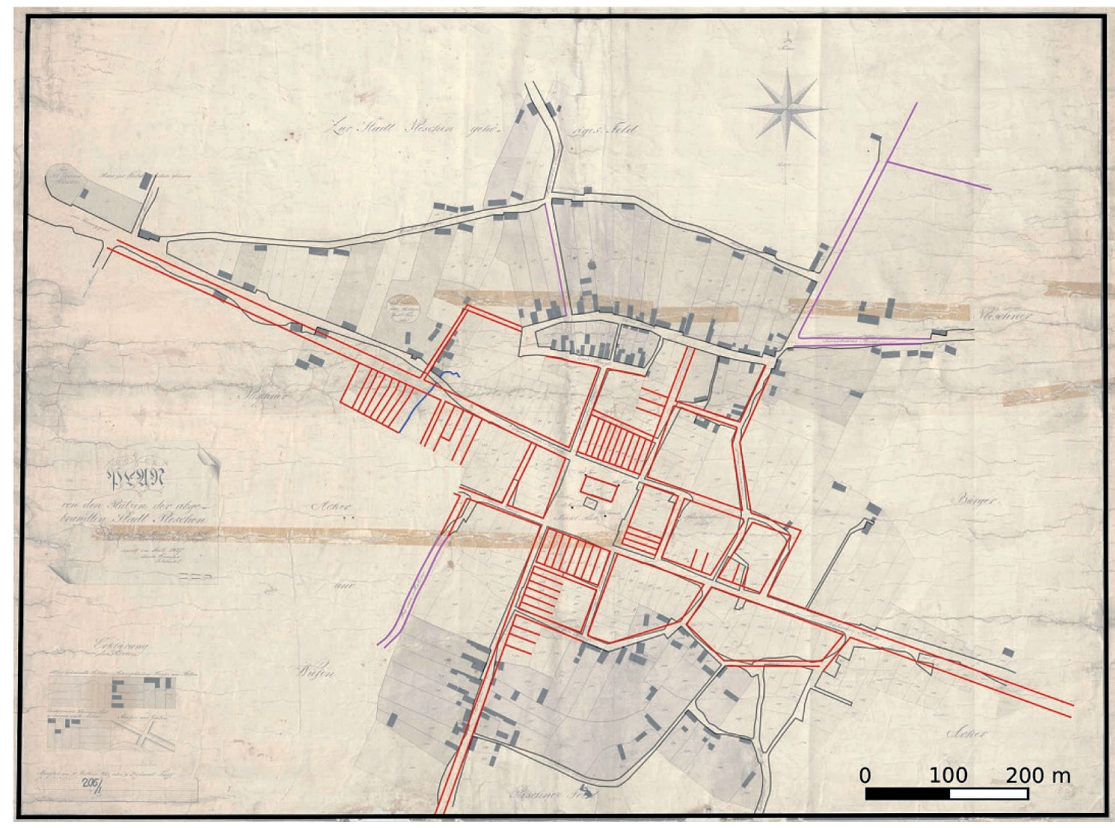

Ryc. 7. Wizualizacja tematyczna 4

Fig. 7. Thematic visualization 4

działek. Nieznacznie zmieniony ład przestrzenny miasta, cechujący się uporządkowaniem, musiał powstać na podstawie dokładnych pomiarów geodezyjnych i na planie został naniesiony wtórnie. Potwierdzenie tego stanowią próby rejestracji planu do współczesnego układu współrzędnych PUWG-1992, w których najlepsze efekty uzyskiwano w przypadku nawiązywania do skrzyżowań dróg na omawianej warstwie. Na podstawie różnic w lokalizacji poszczególnych obiektów i ich kształtów oraz prób nadania georeferencji stwierdzono, że omawianą warstwę cechuje kartometryczność w porównaniu z pozostałą treścią planu.

\section{WNIOSKI}

Z przeprowadzonych badań zasobu informacyjnego wynika, że analizując zakres treści dawnych map, nie można ograniczać się wyłącznie do badania zasobu legendy. Na planie pojawiały się oznaczenia, które nie miały objaśnień w legendzie, mimo to wzbogacały cały przekaz o nowe informacje przestrzenne. $\mathrm{W}$ trakcie badań scharakteryzowano wszystkie elementy treści planu i zaproponowano sposób ich uporządkowania. Zapis poszczególnych obiektów do osobnych warstw ukazał możliwość doboru treści według różnych kryteriów i przedstawiania ich w postaci wizualizacji tematycznych. Prezentowana forma zapisu może 
stanowić podstawę do tworzenia kompilacji XIX-wiecznego planu z innymi opracowaniami z tego okresu oraz ze współczesnymi mapami i bazami danych.

$\mathrm{Z}$ uzyskanych rezultatów badań wynika, że cyfrowy zapis dawnego planu zwiększa możliwości jego wykorzystania w badaniach. Taki sposób użytkowania map stanowi odwołanie do koncepcji sześcianu MacEachrena (1994), gdzie jednym z trzech kryteriów (wyrażonych przez osie trójwymiarowej bryły) była interaktywność, czyli stopień wykorzystania współczesnej technologii chociażby w postaci programów graficznych czy geoinformacyjnych (Medyńska-Gulij 2015). Tradycyjny sposób użytkowania map analogowych nie wymaga wykorzystywania narzędzi interaktywnych, przez co mają one niską pozycję w sześcianie, a to oznacza, że służą głównie do prezentacji danych. Zwiększenie stopnia interaktywności przez zaimplementowanie tychże map do specjalistycznych programów podnosi ich pozycję w sześcianie do poziomu umożliwiającego badanie nowych relacji.

W przeprowadzonym postępowaniu badawczym występowały trudności związane z jakością materiału źródłowego. Przetarcia papieru w kilku miejscach uniemożliwiały poprawny odczyt treści. Największy jednak problem stanowiło zróżnicowanie kolorystyczne na oryginalnym arkuszu. Po około 200 latach od powstania opracowania kolor stracił wyrazistość do tego stopnia, że na skanach lub fotografiach delikatne różnice odcieni kolorów były często niewidoczne. Do przeprowadzenia opisanych w niniejszym artykule czynności konieczna była praca na oryginalnej wersji planu, a pomimo tego występowały sytuacje trudne do jednoznacznej interpretacji.

Zaprezentowany sposób zapisu treści planu Pleszewa ukazuje duży zasób informacyjny, a wizualizacje tematyczne stanowią propozycję doboru poszczególnych warstw. Przedstawione etapy postępowania nie oznaczają procesu zamkniętego, ale otwierają możliwości dalszego rozwijania takiego ujęcia dawnych opracowań kartograficznych. Kolejny etap może stanowić stworzenie bazy danych zawierającej informacje opisowe pozyskiwane z opracowań kartograficznych lub literatury (Lorek 2016). Taka postać zapisu pozwala na prowadzenie analiz przestrzennych zarówno na zmieniających się w czasie obiektach, np. układ dróg, rozkład zabudowy, a także ich cechach (atrybutach), np. nazwy ulic, numeracja działek.

Praca finansowana z grantu Narodowego Centrum Nauki numer 2013/11/B/HS3/03905.

\section{SPIS LITERATURY}

Buczek K., 1963: Dzieje kartografii polskiej od XV do XVIII wieku: zarys analityczno-syntetyczny, Zakł. Narodowy im. Ossolińskich, Wrocław.

De Coene K., Ongena T., Stragier F., Vervust S., Bracke W., De Maeyer P., 2012: Ferraris, the Legend, The Cartographic Journ., 49(1), 30-42. 
Edney M.H., 1996: Theory and the History of Cartography, Imago Mundi 48 (January), 185-191. Engberg-Pedersen A., 2015: Empire of Chance: The Napoleonic Wars and the Disorder of Things, Harvard Univ. Press Cambridge, Massachusetts.

Gulczyński A., 2012: Społeczeństwo w przestrzeni miejskiej, Rocznik Pleszewski 2011, Muzeum Regionalne w Pleszewie.

Gulczyński A., 2014: Trwanie w życiu miasta, Rocznik Pleszewski 2013, Muzeum Regionalne w Pleszewie.

Hajdasz W., Marciniak M., Przybysz A., Ptak A., Staszak A., 2009: Wędrówki po dawnym Pleszewie, Muzeum Regionalne w Pleszewie oraz Urząd Miasta i Gminy Pleszew.

Lorek D., 2011: Potencjat informacyjny map topograficznych Urmesstischblätter z lat 1822-33 z terenu Wielkopolski, Zakł. Kartografii i Geomatyki UAM, Poznań.

Lorek D., 2016: Multimedia integration of cartographic source materials for researching and presenting phenomena from economic history, Geodesy and Cartography, 66(2).

MacEachren A.M., 1994: Visualization in modern cartography. Modern cartography series, Pergamon, Oxford.

Medyńska-Gulij B., 2015: Kartografia. Zasady i zastosowania geowizualizacji, Wyd. PWN, Warszawa.

Medyńska-Gulij B., Lorek D., 2008: Pruskie mapy topograficzne dla Wielkopolski do 1803 roku, Bad. Fizjogr., Geogr. Fiz., Ser. A, 59, 29-42.

Ptak A., 2007: Samorzad miejski Pleszewa w okresie międzywojennym (1919-1939), Pleszewskie Towarzystwo Kulturalne i Muzeum Regionalne w Pleszewie, Pleszew.

Taylor D.R.F., 1991: A conceptual basis for cartography: new directions for the information era, Cartographic Journ., Vol. 28. No. 2. 